\title{
"The impact of COVID-19 pandemic on performance of small enterprises that are e-commerce adopters and non-adopters"
}

\begin{tabular}{|c|c|c|}
\hline \multirow{4}{*}{ AUTHORS } & \multicolumn{2}{|l|}{$\begin{array}{l}\text { Dirga Lestari } \\
\text { Saida Zainurossalamia ZA (iD) }\end{array}$} \\
\hline & \multicolumn{2}{|l|}{ Siti Maria (1D) } \\
\hline & \multicolumn{2}{|l|}{ Wirasmi Wardhani (iD } \\
\hline & \multicolumn{2}{|l|}{ Rizky Yudaruddin (iD) } \\
\hline ARTICLE INFO & \multicolumn{2}{|c|}{$\begin{array}{l}\text { Dirga Lestari, Saida Zainurossalamia ZA, Siti Maria, Wirasmi Wardhani and } \\
\text { Rizky Yudaruddin (2021). The impact of COVID-19 pandemic on performance of } \\
\text { small enterprises that are e-commerce adopters and non-adopters. Problems and } \\
\text { Perspectives in Management, 19(3), 467-477. doi:10.21511/ppm.19(3).2021.38 }\end{array}$} \\
\hline DOI & \multicolumn{2}{|c|}{ http://dx.doi.org/10.21511/ppm.19(3).2021.38 } \\
\hline RELEASED ON & \multicolumn{2}{|l|}{ Monday, 27 September 2021} \\
\hline RECEIVED ON & \multicolumn{2}{|l|}{ Tuesday, 03 August 2021} \\
\hline ACCEPTED ON & \multicolumn{2}{|l|}{ Wednesday, 15 September 2021} \\
\hline & \multicolumn{2}{|l|}{$(c) \mathbf{E Y}^{\mathrm{E}}$} \\
\hline LICENSE & \multicolumn{2}{|c|}{$\begin{array}{l}\text { This work is licensed under a Creative Commons Attribution } 4.0 \text { International } \\
\text { License }\end{array}$} \\
\hline JOURNAL & \multicolumn{2}{|c|}{ "Problems and Perspectives in Management" } \\
\hline ISSN PRINT & \multicolumn{2}{|l|}{$1727-7051$} \\
\hline ISSN ONLINE & \multicolumn{2}{|l|}{$1810-5467$} \\
\hline PUBLISHER & \multicolumn{2}{|c|}{ LLC "Consulting Publishing Company "Business Perspectives" } \\
\hline FOUNDER & \multicolumn{2}{|c|}{ LLC "Consulting Publishing Company "Business Perspectives" } \\
\hline$\sigma^{0}$ & 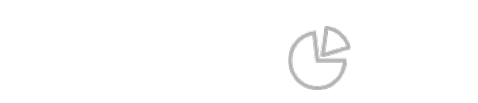 & ニ泣 \\
\hline NUMBER OF REFERENCES & NUMBER OF FIGURES & NUMBER OF TABLES \\
\hline 50 & 0 & 7 \\
\hline
\end{tabular}

(C) The author(s) 2021. This publication is an open access article. 


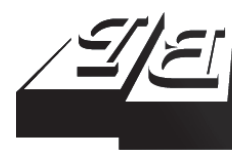

\section{BUSINESS PERSPECTIVES}

LLC "CPC "Business Perspectives" Hryhorii Skovoroda lane, 10, Sumy, 40022, Ukraine www.businessperspectives.org

Received on: $3^{\text {rd }}$ of August, 2021 Accepted on: $15^{\text {th }}$ of September, 2021 Published on: $27^{\text {th }}$ of September, 2021

(c) Dirga Lestari, Saida Zainurossalamia ZA, Siti Maria, Wirasmi Wardhani, Rizky Yudaruddin, 2021

Dirga Lestari, Dr., Lecturer, Faculty of Economics and Business, Department of Management, Mulawarman University, Indonesia.

Saida Zainurossalamia ZA, Dr., Lecturer, Faculty of Economics and Business, Department of Management, Mulawarman University, Indonesia.

Siti Maria, Dr., Lecturer, Faculty of Economics and Business, Department of Management, Mulawarman University, Indonesia.

Wirasmi Wardhani, Dr., Lecturer, Faculty of Economics and Business, Department of Management. Mulawarman University, Indonesia

Rizky Yudaruddin, M.Sc., Lecturer, Faculty of Economics and Business, Department of Management, Mulawarman University, Indonesia. (Corresponding author)
Dirga Lestari (Indonesia), Saida Zainurossalamia ZA (Indonesia), Siti Maria (Indonesia), Wirasmi Wardhani (Indonesia), Rizky Yudaruddin (Indonesia)

\section{THE IMPACT OF COVID-19 PANDEMIC ON PERFORMANCE OF SMALL ENTERPRISES THAT ARE E-COMMERCE ADOPTERS AND NON-ADOPTERS}

\begin{abstract}
Researchers have emphasized the role of e-commerce for small enterprises in improving their performance. However, there is limited evidence on the use of e-commerce by small enterprises, and e-commerce adopters and non-adopters dealing with COVID-19. Therefore, the purpose of this study is to investigate the differences in the impact of COVID-19 on income between small enterprises that are adopters and non-adopters of e-commerce. This study also explored the impact of restrictions on community activities, the intention to adopt e-commerce, and the types of assistance required by small enterprises due to the pandemic. Data were collected through an online questionnaire survey among small enterprises that operate in the culinary field (1,024 small enterprises in Indonesia). The data were analyzed using descriptive analysis, cross-tabulation, and the Mann-Whitney test. This study finds that nonadoption of e-commerce caused small enterprises to experience a decline in income, which worsened due to restrictions of community activities, compared to adopters of e-commerce. Therefore, to overcome this negativity, small enterprises were pushed to adopt e-commerce. Finally, working capital assistance is the main assistance required due to the pandemic both by e-commerce adopters and non-adopters. This study has significant implications for how small enterprises and governments may benefit from e-commerce dealing with extreme disruptions such as the COVID-19 pandemic.
\end{abstract}

Keywords technological, achievement, entrepreneurship, health, benefits

\section{JEL Classification O32, L21, L25, I15}

\section{INTRODUCTION}

Small and medium-sized enterprises (SMEs) are vital to the economies of developing countries such as Indonesia, particularly in terms of job creation, unemployment reduction, and GDP added value. According to the Republic of Indonesia's Ministry of Cooperatives and Small and Medium-Sized Enterprises, the country is speculated to have approximately 64 million MSME participants by 2020 , contributing $61 \%$ and $97 \%$ to the GDP and employment.

Similarly, Indonesia is relatively the fourth country with the largest number of internet users at approximately 185 million. The sheer size of the market combined with the high level of digital literacy among its customers is apparently one of the reasons the country's e-commerce industry has grown to become the largest in Southeast Asia, accounting for over half of the region's total market size. During the pandemic, the trend towards e-commerce was further emphasized, with the country emerging as one of the region's most aggressive users of technology with the greatest rates of mobile e-commerce and e-commerce adoption, reaching 78\% in October 2020 (Deloitte, 2021). 
Several preliminary studies have reported that the use of digital technology, particularly in e-commerce, plays a significant role in deciding SMEs' success (Rahayu \& Day, 2017; Ajibade et al., 2019; Alzahrani, 2019; Brewera \& Sebby, 2021; Breckova \& Karas, 2020; Syaifullah et al., 2021). However, the evidence on the role of e-commerce in explaining the performance of SMEs' funding decisions is ambiguous (Nooteboom, 2006; Tapscott, 2001; Molla \& Heeks, 2007; Ho, 2011; Hamad et al., 2018). Moreover, involvement in the digital economy and the adoption of e-commerce is the key to the increased survivability of many businesses. However, $42 \%$ of offline SMEs were compelled to close their doors during the COVID-19 epidemic, while the remaining 24\% operated online (Deloitte, 2021).

E-commerce is beneficial to both producers and consumers. It is easier for producers to attain market shares that would otherwise be impossible to obtain through traditional means. E-commerce also makes distribution routes more efficient, therefore, SMEs need to actively participate in the digital economy and embrace its transformation to stay up to date. The pandemic has undoubtedly reduced the purchasing capacity of the general public due to the decrease in outdoor activities to halt the virus's spread. Therefore, many consumers have distanced themselves from traditional retailers and become engaged in online purchases. This forced many SMEs that failed to embrace digital transformation to be shut down due to a decline in consumer patronage.

The purpose of this study is to compare the influence of the COVID-19 epidemic on small enterprises that are adopters and non-adopters of e-commerce. Additionally, the impact of restrictions on community activities, the desire to adopt e-commerce, and the various support systems necessary for small enterprises affected by the COVID-19 pandemic were also examined. The data were acquired from an online questionnaire survey carried out in 2021 among Indonesian culinary small enterprises.

\section{LITERATURE REVIEW AND HYPOTHESES DEVELOPMENT}

SMEs play a critical role in the local, national, and worldwide economy by creating jobs and income (Chatterjee et al., 2015). In both developed and developing countries, it accounts for at least $90 \%$ of all businesses. Meanwhile, in developed and emerging countries, it contributes to approximately 40 to $60 \%$ of global GDP, $40 \%$ of industrial production, and accounts for $35 \%$ of worldwide exports (Igwe et al., 2018; Mbuyisa \& Leonard, 2017; Sharma \& Bhagwat, 2006). Furthermore, with almost $99 \%$ of non-financial companies, $58 \%$ of the total value created, and $66.8 \%$ of the entire employment opportunities, SMEs represent the backbone of the European economy (Briozzo \& Cardone-Riportella, 2012). In Japan, SMEs account for over $99.7 \%$ of all firms and $70 \%$ of the workforce (Yoshino \& Taghizadeh-Hesary, 2018). In 2014, it accounted for $99.8 \%$ of all businesses in Turkey, with $55.1 \%$ and $37.7 \%$ contributing to the export and import sectors, respectively (Kaya \& Uzay, 2017). In Indonesia, 64 million MSME actors have contributed $61 \%$ of GDP and $97 \%$ of employment opportunities (BPS, 2019; Yudaruddin, 2020).

The COVID-19 pandemic's effect on SMEs was documented in many countries. It had an enormous economic impact in China, and this increased considerably as the country tightened its trade restrictions. According to $\mathrm{Lu}$ et al. (2020), China's lockdown policy to contain the virus had a severe impact on the cash flow of SMEs. Keogh-Brown et al. (2020) proved that the pandemic had a negative impact on the ability of entrepreneurs in the United Kingdom to get entrepreneurial funding. Some research further revealed that SMEs in the United States were financially vulnerable (Juergensen et al., 2020; Bartik et al., 2020). Additionally, numerous multinational corporations have considerably restricted their commercial activity due to raw material supply shortages. Meanwhile, SMEs with short-term commercial agreements are also under pressure due to the epidemic outbreak (Tairas, 2020).

In Indonesia, Ssenyonga and Shafiullah (2021) reported the economic and social implications of the pandemic. The decline in aggregate demand was due to the decrease in household and compa- 
ny spending, with a surge in unemployment due to investments and exports. The government's quick response helped mitigate the crisis impact on the economy and vulnerable societal segments. The pandemic exacerbated the Indonesian economy's pre-existing fundamental problems, such as de-industrialization and inter-regional digital division. Tairas (2020) reported the various obstacles faced by SMEs during the pandemic COVID-19 that occurred earlier in the year. Some of the challenges were encountered in manufacturing goods and services due to scarcity of raw materials, lack of financial liquidity, and decline in demand. Hermina et al. (2020) stated that external circumstances such as rivalry and customers negatively affected SME performance during the COVID-19 pandemic in West Java, Indonesia.

Additionally, social isolation is also one of the obstacles that SMEs need to overcome. The only non-pharmaceutical technique for preventing COVID-19 transmission is to limit activities that bring a large number of people together (Lewnard \& Lo, 2020). Eliminating these activities is a form of social isolation. Anderson et al. (2020) stated that the secret to social separation is isolating oneself and seeking remote medical care only when symptoms are severe. This entails withdrawing from crowds and acquiring knowledge that helps one avoid the spread and transmission of the virus. SMEs are expected to have a chance of survival during the pandemic, supposing they adhere to the health guidelines (Saidu \& Aifuwa, 2020). However, in terms of the economy, social distance has led to a reduction in SMEs' sales as a result of the ban of activities in public places. Pandemic has affected all facets (Thorgren \& Williams, 2020), although there is a more serious matter about instituting social lockdowns or distancing measures that disproportionately harm SMEs. The findings of some preliminary studies reported that the social distancing policy has a substantial impact on business actors, particularly SMEs. In Indonesia, these small and medium-sized enterprises' operations were affected by their inability to operate normally, resulting in decreased demand and income (Lutfi et al., 2020).

Globally, societies were under lockdown, and residents were urged to maintain social isolation and remain at home. As social beings, seclusion tends to be detrimental to peoples' health (Cacioppo \&
Hawkley, 2009). Aloneness has been associated with impaired mental performance, unhelpfulness, desolation, and vulnerability to community hazards. There are indications that these problems were persistent during the pandemic, as witnessed by the increase in domestic violence, neighbor disputes, and handgun sales (Campbell, 2020). Another consequence of lockdowns was the exponential growth in social media and internet use. The earlier studies stated that individuals who are lonely use social media more often and, in some cases, prefer it over face-to-face contact (Nowland et al., 2018). This was an opportunity for SMEs during the COVID-19 pandemic to survive. However, there is no guarantee that the use of technology during a health crisis is bound to improve SME performance.

E-commerce is the online buying and selling of goods and services, and additionally participating in monetary transactions and selling services or commodities. Through e-commerce operations, businesses may reach the greatest number of customers imaginable. There is no one definition of e-commerce that is widely recognized, with many writers providing their own interpretations. According to Turban (2010), it is a term that refers to a method of selling or purchasing goods over the internet or an intranet. Laudon and Traver (2017) defined e-commerce as a business transaction between people that involves the exchange of value through or via the use of digital technology. According to Botha et al. (2004), e-commerce is the electronic exchange of information between business and its customers or suppliers to place orders. The internet has developed into a crucial component of the business. While Li and Xie (2012) define e-commerce as the electronic purchase and sale of products or services through web browsers.

Numerous studies stated that the application of digital technologies, particularly e-commerce, contributes to the success of SMEs. However, its role in explaining the performance of SMEs' funding decisions is equivocal. On the one hand, some studies reported that e-commerce improves SME performance. Integration of information technology enhances the performance of South African SMEs (Ajibade et al., 2019). Regarding Saudi Arabian SMEs, Alzahrani (2019) reported that the adoption of e-commerce affects the strategy of SMEs. Restaurant operators connect to 
their target demographic in the US through the online ordering system (Brewera \& Sebby, 2021). This technology enables the creation and promotion of products in the Czech Republic (Breckova \& Karas, 2020). Syaifullah et al. (2021) executed a study in Indonesia and discovered that marketing through social networking sites has a good effect on SME performance. Additionally, Rahayu and Day (2017) stated that a higher degree of e-commerce adoption offers more benefits.

On the contrary, some research has proven that SME performance does not significantly enhance e-commerce. Nooteboom (2006) discovered that the influence of technological adoption on transaction costs differs depending on the situation. Some tend to be reduced due to the adoption of new technologies. Based on the fact that virtually all industries use the internet, it is not considered a source of competitive advantage (Tapscott, 2001). According to Molla and Heeks (2007), there is no convincing evidence that supports the fact that e-commerce is advantageous for South African companies. Ho (2011) stated that there is no unambiguous link between the strategic position of SMEs and e-commerce abilities, irrespective of the recommendation to engage in apps for e-commerce. Hamad et al. (2018) discovered that Egyptian SMEs engaged in manufacturing are still grappling with the relationship between competitive advantage and e-commerce, which is the most significant component in creating strategic plans.

Many SMEs have made integrating e-commerce into their company operations a priority and gaining significant attraction. However, SMEs in Indonesia are slowly adopting e-commerce (Busnetti \& Tambunan, 2020). Numerous variables influence small businesses' use of e-commerce. In Jordan, relative advantages and information technology proficiency affect its continued intention to use e-commerce (Lubna \& Baharudin, 2017). Government assistance directly affects Ghanaian SMEs' plans to adopt e-commerce (Awiagah et al., 2016). In Indonesia, it is influenced by several variables, including perceived advantages, technological preparedness, owners' innovativeness, IT experience, and capability (Rahayu \& Day, 2015).

COVID-19 had a severe impact on SMEs and their employees, particularly in Indonesia. Therefore, it is important to determine SMEs' needs and the factors responsible to effectively assist them in subsequent disasters. Studies carried out on SMEs during the pandemic stated that these businesses received various forms of help. Gourinchas et al. (2020) stated that suspending interest payments has a negligible influence on company failures. Strictly tailored treatments have a significantly greater impact at a relatively low cost. A cross-country survey of firms was conducted to determine the amount of cash and liquidity required by SMEs and whether these businesses have the capacity on their balance sheets to take on additional loans. Significant differences were discovered among nations, thereby proving that the liquidity problem faced by SMEs varies. Liu and Parilla (2020) demonstrated that the liquidity problem faced by small companies differs significantly among regions and cities in the United States.

Meanwhile, ILO (2020) identified strategies to assist SMEs in Indonesia during the epidemic of COVID-19. These include improved access to finance and working capital to assist with shortterm cash flow through grants, cheap loans, or temporary tax exemptions. The second is increasing the demand for products and services, such as assistance with interim conversions relating to COVID-19 needs. The third is preserving employment and social protection, namely subsidy programs that assist employees in maintaining their jobs. The fourth is encouraging companies to reactivate when the infection has been contained. This is because businesses are bound not to resume normalcy, and companies need assistance adapting to the changing market conditions. Finally, when workers and employers confront a crisis together, social discussion and cohesiveness improve a country's resilience. Thus, the study develops the following hypotheses:

H1: There is a significant difference in performance (decrease in income) between small enterprises that are e-commerce adopters and non-adopters.

H2: There is a significant difference in performance (restrictions to community activities worsen small enterprise performance) between small enterprises that are e-commerce adopters and non-adopters. 


\section{METHODOLOGY}

A quantitative technique was adopted to evaluate the conceptual foundation and to address the research issues. Therefore, this study used data from an online questionnaire survey carried out in May 2021-June 2021 among Indonesian culinary small enterprises. This was selected because it offers numerous advantages over traditional approaches, including being less expensive, having a higher response rate, as well as being rapid and simple (Rahayu \& Day, 2017). The questionnaire was divided into 3 parts. The first one is based on the respondents' profiles. The second part is centered on the differences related to the impact of COVID-19 on small enterprises based on the category of e-commerce adoption. The last part concerns the intention to adopt e-commerce. This refers to a method of selling or purchasing goods over the internet or an intranet (Turban, 2010).

The majority of the data acquired pertains to parties interested in small enterprises. For instance, through the Republic of Indonesia's Ministry of Cooperatives and Small and MediumSized Enterprises (Kementrian Koperasi dan Usaha Kecil Menengah Republik Indonesia), the Indonesian government publishes data on small enterprise activities in certain sectors. According to the Republic of Indonesia's Law No. 20 of 2008, MSMEs are companies with assets ranging from 50 million to 500 million rupiahs and annual revenue ranging from 300 million to 2.5 billion rupiahs. These enterprises are operated by their owners or by a small number of workers.

The survey utilized descriptive analysis to elucidate the fundamental aspects of the data, which included frequency. According to Lutfi et al. (2020), the acquired data were examined using the SPSS program. Descriptive statistical data were used to explain the samples in a legitimate and relevant way by representing them in a numerical form and the most straightforward feasible manner. Moreover, cross-tabulation was frequently used to classify data into mutually exclusive categories (Yudaruddin, 2014). Additionally, the Mann-Whitney test is used in this study. The objective of this study is to determine whether there is a difference in performance between small enterprises that have adopted or have not adopted e-commerce. The Mann-Whitney test is a non-parametric statistical test used to examine an independent sample that consists of two unrelated samples. This test serves the same purpose as the t-test for parametric statistics; however, the t-test for parametric statistics requires that the data be distributed normally; when the normal distribution assumption is violated for interval and ratio scale data, another alternative is to use this test instead of the t-test. The Mann-Whitney test can be used to determine this (Yudaruddin, 2014).

\section{RESULTS}

The respondents are owners of small enterprises. A total of 1,024 respondents, comprising 594 (58\%) females and 430 (42\%) males, participated in this survey. Furthermore, in terms of age, small enterprises that use e-commerce are led by those aged between 20 to 30 years (31\% or 321 respondents). Conversely, those that do not use e-commerce are within the ages of 41 to 50 years (14.7\%). In terms of educational background, it was discovered that 257 or $25.1 \%$ and 228 or $28.1 \%$ of the owners of both small enterprises that use e-commerce and those that did not adopt it were educated, as shown in Table 1.

Table 2 provides information on the differences in the distribution of income between adopters and non-adopters of e-commerce in small enterprises. The results show that as many as 883 or $86.2 \%$ of the total 1,024 respondents experienced a decrease in income as a result of the epidemic, while only $13.8 \%$ stated otherwise. As many as 357 or $34.9 \%$ of the respondents experienced a relatively $10-<25 \%$ decline in income. Furthermore, there is a tendency for e-commerce adopters to experience a higher decline compared to non-adopters. E-commerce adoption by small enterprises which experienced a $10-<25 \%, 25-<50 \%$, and $>50 \%$ decrease in revenue, were $34.9 \%, 14.1 \%$, and $2.5 \%$, respectively. Meanwhile, non-adopters of e-commerce in small enterprises that experienced a $10-$ $<25 \%, 25-<50 \%$, and $>50 \%$ decrease in revenue, were $37.5 \%, 16.6 \%$ and $3.4 \%$ respectively. In addition, the number of e-commerce adopters that did not experience a decrease in revenue during the COVID-19 pandemic was greater than non-adopters. Overall, non-adopters of e-commerce experienced a decline in income due to the pandemic. 
Table 1. Profile of respondents $(N=1024)$

\begin{tabular}{|c|c|c|c|}
\hline Categories & E-commerce adopters & Non-adopters of e-commerce & All respondents \\
\hline Male & $203(19.8 \%)$ & $227(22.2 \%)$ & $430(42 \%)$ \\
\hline Female & $322(31.4 \%)$ & $272(26.6 \%)$ & $594(58 \%)$ \\
\hline \multicolumn{4}{|l|}{ Age } \\
\hline$<20$ & $35(3.4 \%)$ & $13(1.3 \%)$ & $48(4.7 \%)$ \\
\hline $20-30$ & $321(31.1 \%)$ & $150(14.6 \%)$ & $471(46 \%)$ \\
\hline $31-40$ & $120(11.7 \%)$ & $121(11.8 \%)$ & $241(23.5 \%)$ \\
\hline $41-50$ & $36(3.5 \%)$ & $151(14.7 \%)$ & $187(18.3 \%)$ \\
\hline$>50$ & $13(1.3 \%)$ & $64(6.3 \%)$ & $77(7.5 \%)$ \\
\hline \multicolumn{4}{|l|}{ Education } \\
\hline Primary school & $15(1.5 \%)$ & $35(3.4 \%)$ & $50(4.9 \%)$ \\
\hline Junior high school & $16(1.6 \%)$ & $75(7.3 \%)$ & $91(8.9 \%)$ \\
\hline Senior high school & $257(25.1 \%)$ & $228(28.1 \%)$ & $545(53.2 \%)$ \\
\hline Diploma/Undergraduate & $228(22.3 \%)$ & $99(9.7 \%)$ & $327(31.9 \%)$ \\
\hline Master/Doctoral & $9(0.9 \%)$ & $2(0.2 \%)$ & $11(1.1)$ \\
\hline
\end{tabular}

To determine whether the average value provided by each group is statistically different and significant, particularly in relation to the decline in performance, as measured by revenue, between small enterprises that are adopters and non-adopters of e-commerce due to COVID-19 (Table 3). The results show that there is a significant difference in performance (decrease in income) between adopters and non-adopters of e-commerce, thereby supporting $H 1$.

Table 4 shows the respondents' responses towards the impact of restricted community ac- tivities on the performance of small enterprises. Approximately 658 or $64.2 \%$ of the respondents responded slightly agree, agree, and strongly agree. This shows that the restriction policy tends to worsen small enterprise performances. Furthermore, the responses of both non-adopters and adopters of e-commerce regarding the impact of the restricted community activities were $32.70 \%$ and $31.60 \%$, respectively. Similarly, restricted community activities negatively affected the performance of small enterprises both for non-adopters and adopters. Moreover, in Table 5, this study analyzes whether there is a significant difference

Table 2. Distribution of decrease in income of small enterprises

\begin{tabular}{|c|c|c|c|c|c|c|c|}
\hline \multirow{2}{*}{$\begin{array}{l}\text { Category of } \\
\text { respondents }\end{array}$} & \multirow{2}{*}{$\begin{array}{l}\text { Is the pandemic of } \\
\text { COVID-19 reducing income? }\end{array}$} & \multicolumn{5}{|c|}{ Distribution of decrease in income } & \multirow{2}{*}{ Total } \\
\hline & & None & $<10 \%$ & $10 \%-<25 \%$ & $25 \%-<50$ & $>50 \%$ & \\
\hline \multirow{4}{*}{$\begin{array}{l}\text { Adopters of } \\
\text { e-commerce }\end{array}$} & \multirow{2}{*}{ Yes } & 0 & 187 & 170 & 74 & 13 & 444 \\
\hline & & $(0.0 \%)$ & $(35.6 \%)$ & $(32.4 \%)$ & $(14.1 \%)$ & $(2.5 \%)$ & $(84.6 \%)$ \\
\hline & \multirow{2}{*}{ No } & 81 & 0 & 0 & 0 & 0 & 81 \\
\hline & & $(15.4 \%)$ & $(0.0 \%)$ & $(0.0 \%)$ & $(0.0 \%)$ & $(0.0 \%)$ & $(15.4 \%)$ \\
\hline \multirow{4}{*}{$\begin{array}{l}\text { Non-adopters of } \\
\text { e-commerce }\end{array}$} & \multirow{2}{*}{ Yes } & 0 & 152 & 187 & 83 & 17 & 439 \\
\hline & & $(0.0 \%)$ & $(30.5 \%)$ & $(37.5 \%)$ & $(16.6 \%)$ & $(3.4 \%)$ & $(88.0 \%)$ \\
\hline & \multirow{2}{*}{ No } & 60 & 0 & 0 & 0 & 0 & 60 \\
\hline & & $(12.0 \%)$ & $(0.0 \%)$ & $(0.0 \%)$ & $(0.0 \%)$ & $(0.0 \%)$ & $(12.0 \%)$ \\
\hline \multirow{4}{*}{ All respondents } & \multirow{2}{*}{ Yes } & 0 & 339 & 357 & 157 & 30 & 883 \\
\hline & & $(0.0 \%)$ & $(33.1 \%)$ & $(34.9 \%)$ & $(15.3 \%)$ & $(2.9 \%)$ & $(86.2 \%)$ \\
\hline & \multirow{2}{*}{ No } & 141 & 0 & 0 & 0 & 0 & 141 \\
\hline & & (13.8\%) & $(0.0 \%)$ & $(0.0 \%)$ & $(0.0 \%)$ & $(0.0 \%)$ & $(13.8 \%)$ \\
\hline
\end{tabular}

Table 3. Mann-Whitney test results for decrease in income of small enterprises

\begin{tabular}{|c|c|c|c|c|c|}
\hline Description & Group & $\mathbf{N}$ & Mean rank & Sum of ranks & Test statistics (Z Table) \\
\hline \multirow{2}{*}{ Decrease in income } & Adopters of e-commerce & 525 & 489.23 & 256845.50 & \multirow{2}{*}{$-2.700 * * *$} \\
\hline & Non-adopters of e-commerce & 499 & 536.98 & 267954.50 & \\
\hline
\end{tabular}

Note: $* * *$ sig at 0.001 . 
Table 4. Impact of restrictions to community activities (RCA)

\begin{tabular}{|c|c|c|c|c|c|c|c|c|}
\hline \multirow{2}{*}{$\begin{array}{l}\text { Category of } \\
\text { respondents }\end{array}$} & \multicolumn{7}{|c|}{ Restrictions to community activities worsen small enterprise performance } & \multirow[b]{2}{*}{ Total } \\
\hline & $\begin{array}{l}\text { Strongly } \\
\text { disagree }\end{array}$ & Disagree & $\begin{array}{c}\text { Slightly } \\
\text { disagree }\end{array}$ & $\begin{array}{c}\text { Neither agree } \\
\text { nor disagree }\end{array}$ & $\begin{array}{c}\text { Slightly } \\
\text { agree }\end{array}$ & Agree & $\begin{array}{c}\text { Strongly } \\
\text { agree }\end{array}$ & \\
\hline \multirow{2}{*}{$\begin{array}{l}\text { Adopters of } \\
\text { e-commerce }\end{array}$} & 22 & 34 & 56 & 89 & 115 & 107 & 102 & 525 \\
\hline & $(2.1 \%)$ & $(3.3 \%)$ & $(5.5 \%)$ & $(8.7 \%)$ & $(11.2 \%)$ & $(10.4 \%)$ & $(10.0 \%)$ & $(51.3 \%)$ \\
\hline \multirow{2}{*}{$\begin{array}{l}\text { Non-adopters of } \\
\text { e-commerce }\end{array}$} & 14 & 21 & 46 & 84 & 96 & 91 & 147 & 499 \\
\hline & $(1.4 \%)$ & $(2.1 \%)$ & $(4.5 \%)$ & $(8.2 \%)$ & $(9.4 \%)$ & $(8.9 \%)$ & $(14.4 \%)$ & $(48.7 \%)$ \\
\hline \multirow{2}{*}{ All respondents } & 36 & 55 & 102 & 173 & 211 & 198 & 249 & 1024 \\
\hline & $(3.5 \%)$ & $(5.4 \%)$ & $(10.0 \%)$ & $(16.9 \%)$ & $(20.6 \%)$ & $(19.3 \%)$ & $(24.3 \%)$ & $(100.0 \%)$ \\
\hline
\end{tabular}

Table 5. Mann-Whitney test results for restrictions to community activities worsen small enterprise performance

\begin{tabular}{|c|c|c|c|c|c|}
\hline Description & Group & $\mathbf{N}$ & $\begin{array}{c}\text { Mean } \\
\text { rank }\end{array}$ & $\begin{array}{c}\text { Sum } \\
\text { of ranks }\end{array}$ & $\begin{array}{c}\text { Test statistics } \\
\text { (Z Table) }\end{array}$ \\
\hline \multirow{2}{*}{$\begin{array}{l}\text { RCA worsen small enterprise } \\
\text { performance }\end{array}$} & Adopters of e-commerce & 525 & 525 & 483.71 & \multirow{2}{*}{$-3.255^{* * *}$} \\
\hline & Non-adopters of e-commerce & 499 & 499 & 542.79 & \\
\hline
\end{tabular}

Note: $* * *$ sig at 0.001 .

in performance (restrictions to community activities worsen small enterprise performance) between non-adopters and adopters of e-commerce. The outcomes of this study find that there is a significant difference in performance (restrictions to community activities worsen small enterprise performance) between e-commerce adoption and non-adopters, thus supporting $\mathrm{H} 2$.

Table 6 displays the findings of intention to apply e-commerce by small enterprises, particularly by non-adopters, during the COVID-19 pandemic. Relatively 266 or $53.3 \%$ of respondents had the in- tention to adopt e-commerce. Approximately 236 (or $47.3 \%$ ) of those who intend to utilize e-commerce are non-adopters who have seen a drop in income as a result of the COVID-19 pandemic. Meanwhile, the remaining 233 small enterprises, or $46.7 \%$, have no plans to use e-commerce, even though $40.7 \%$ have seen a reduction in income as a result of the pandemic.

Table 7 shows the types of assistance that need to be offered to these small enterprises. Working capital is the major assistance required by both e-commerce adopters and non-adopters. Similarly,

Table 6. Intention to adopt e-commerce

\begin{tabular}{|c|c|c|c|c|}
\hline \multirow{2}{*}{$\begin{array}{l}\text { Category of } \\
\text { respondents }\end{array}$} & \multirow{2}{*}{$\begin{array}{l}\text { Is the COVID-19 pandemic } \\
\text { reducing income? }\end{array}$} & \multicolumn{2}{|c|}{ Is there an intention to adopt e-commerce? } & \multirow{2}{*}{ Total } \\
\hline & & Yes & No & \\
\hline \multirow{4}{*}{$\begin{array}{l}\text { Non-adopters of } \\
\text { e-commerce }\end{array}$} & \multirow{2}{*}{ Yes } & 236 & 203 & 439 \\
\hline & & $47.3 \%$ & $40.7 \%$ & $88.0 \%$ \\
\hline & \multirow{2}{*}{ No } & 30 & 30 & 60 \\
\hline & & $6.0 \%$ & $6.0 \%$ & $12.0 \%$ \\
\hline
\end{tabular}

Table 7. Types of assistance required due to the COVID-19 pandemic

\begin{tabular}{|c|c|c|c|c|c|c|}
\hline Category of respondents & $\begin{array}{c}\text { Working } \\
\text { capital } \\
\text { assistance }\end{array}$ & $\begin{array}{c}\text { Ease of loan } \\
\text { application } \\
\text { administration }\end{array}$ & $\begin{array}{l}\text { Electricity bill } \\
\text { reduction }\end{array}$ & $\begin{array}{l}\text { Tax rate } \\
\text { reduction }\end{array}$ & $\begin{array}{l}\text { Loan } \\
\text { restructuring }\end{array}$ & Other \\
\hline \multirow{2}{*}{ Adopters of e-commerce } & 277 & 46 & 95 & 36 & 28 & 43 \\
\hline & $(27.1 \%)$ & $(4.5 \%)$ & $(9.3 \%)$ & $(3.5 \%)$ & $(2.7 \%)$ & $(4.2 \%)$ \\
\hline \multirow{2}{*}{ Non-adopters of e-commerce } & 279 & 32 & 87 & 35 & 31 & 35 \\
\hline & $(27.2 \%)$ & $(3.1 \%)$ & $(8.5 \%)$ & $(3.4 \%)$ & $(3.0 \%)$ & $(3.4 \%)$ \\
\hline \multirow{2}{*}{ All respondents } & 556 & 78 & 182 & 71 & 59 & 78 \\
\hline & (54.3\%) & (7.6\%) & (17.8\%) & (6.9\%) & (5.8\%) & $(7.6 \%)$ \\
\hline
\end{tabular}


approximately 556 or $54.3 \%$ of the respondents chose working capital as the much-needed assistance as a result of the COVID-19 pandemic. Conversely, 182 or $17.8 \%$ of the respondents selected electricity bill reduction as the much-needed assistance during the pandemic.

\section{DISCUSSION}

The increasing growth of an online business, which provides several conveniences, time efficiency, energy efficiency, and cost efficiency, is undoubtedly a positive development potential for SMEs. SMEs are a critical economic sector for competitive economic development; moreover, in Indonesia, this sector is a source of livelihood. SMEs are prevalent in the trade, industrial, and culinary sectors. The culinary industry is the most active and in-demand by business actors. However, many culinary enterprises have yet to implement e-commerce into their operations.

This study provides an overview of the differences in the impact of the pandemic on small enterprises that are e-commerce adopters and non-adopters. The differences in the distribution of income are also shown in Table 2 and Table 3. Indeed, all small enterprises experienced a decline in income. However, non-adopters of e-commerce experienced a greater decline in income compared to its adopters. These results display the importance of adopting e-commerce for small enterprises during COVID-19. Several studies have suggested that SMEs' use of digital technology, particularly e-commerce, plays a role in their success. Ajibade et al. (2019), Alzahrani (2019), Brewera and Sebby (2021), Breckova and Karas (2020), Syaifullah et al. (2021), and Rahayu and Day (2017) reported that SMEs with e-commerce adoption reaped more benefits.

COVID-19 had an extremely negative influence on every aspect. However, the greater worry was associated with imposing social lockdowns or distancing measures that disproportionately damaged SMEs (Thorgren \& Williams, 2020; Lutfi et al., 2020). Table
4 shows the respondents' responses to the impact of restricted community activities on small enterprises' performances. Meanwhile, Table 5 shows that there is a significant difference in performance (restrictions to community activities worsen small enterprise performance) between e-commerce adopters and non-adopters. Indeed, these prohibitions disrupted the inability of small enterprises to operate normally, thereby resulting in a decline in demand and income. However, non-adopters of e-commerce were badly affected compared to its adopters. These findings indicate that e-commerce has a role in not aggravating the performance conditions of small enterprises when restrictions were placed on community activities.

Table 6 shows the results regarding the intention to adopt e-commerce by small enterprises. The non-adopters of e-commerce intend to adopt digital technology after experiencing a decline in income due to the pandemic. This shows that the negative impact of COVID-19 forced small enterprises to adopt e-commerce. Similarly, e-commerce integration into business operations has become a goal for small enterprises to deal with the pandemic. These results confirm those of Rahayu and Day (2015), who claimed that several factors, including perceived benefits, influence SMEs' adoption of e-commerce in Indonesia. However, in terms of technology usage, this study reported that the bulk of SME marketing efforts are conducted through e-commerce (Rahayu \& Day, 2017).

The COVID-19 pandemic has been particularly harsh on small and medium-sized companies and their employees, notably in Indonesia. Therefore, what do SMEs want, and what has worked in prior disasters to assist them in surviving? Table 7 explores the types of assistance required for their survival. Working capital is the major assistance required by both e-commerce adopters and non-adopters. This is in line with the findings of Liu and Parilla (2020), who stated that the liquidity problem faced by these small companies differs significantly among regions and cities in the United States.

\section{CONCLUSION}

This study investigates different impacts of the pandemic on income generated by both adopters and non-adopters of e-commerce. The impact of restrictions on community activities, the intention to adopt e-commerce, 
and the types of assistance required due to the COVID-19 pandemic were also explored. This study used data from an online questionnaire survey carried out in 2021 among Indonesian culinary small enterprises. The survey utilized descriptive analysis to elucidate the fundamental aspects of the data, which included frequency. Moreover, cross-tabulation was also adopted in this study. Additionally, the Mann-Whitney test was used.

It was discovered that firstly, non-adoption of e-commerce caused small enterprises to experience a huge decline in income due to the COVID-19 pandemic compared to the e-commerce adopters. Secondly, restrictions placed on community activities worsened performance of small enterprises that have not adopted e-commerce. Thirdly, the negative impact of the pandemic pushed small enterprises to adopt e-commerce. Finally, working capital is the major assistance required by both e-commerce adopters and non-adopters.

This study has several important implications and policies. First, these findings tend to help small enterprise owners better grasp the potential benefits of e-commerce, particularly in response to the COVID-19 pandemic and restricted community activities. Secondly, these results provide more specific targets for the government to encourage small enterprises to integrate e-commerce into their business operations. Thirdly, the findings show that working capital is necessary assistance for both e-commerce adopters and non-adopters. This study has some limitations in terms of sampling as it comprises only small enterprises. In addition, it only focuses on small enterprises in the culinary field. Therefore, future studies need to explore other sectors deeply.

\section{AUTHOR CONTRIBUTIONS}

Conceptualization: Dirga Lestari.

Data curation: Rizky Yudaruddin, Saida Zainurossalamia.

Formal analysis: Saida Zainurossalamia, Wirasmi Wardhani.

Funding acquisition: Dirga Lestari.

Investigation: Rizky Yudaruddin.

Methodology: Saida Zainurossalamia, Wirasmi Wardhani, Siti Maria.

Project administration: Siti Maria.

Resources: Saida Zainurossalamia, Rizky Yudaruddin.

Software: Rizky Yudaruddin.

Supervision: Dirga Lestari.

Validation: Dirga Lestari.

Visualization: Saida Zainurossalamia.

Writing - original draft: Dirga Lestari.

Writing - review \& editing: Wirasmi Wardhani.

\section{ACKNOWLEDGMENT}

We are grateful to Mulawarman University for providing us with the funding necessary to gather the necessary data for the study and complete this empirical investigation. We also would like to thank two anonymous reviewers and seminar participants at Mulawarman University for their helpful feedback.

\section{REFERENCES}

1. Ajibade, P., Ondari-Okemwa,

E. M., \& Matlhako, M. M. (2019). Information technology integration for accelerated knowledge sharing practices: challenges and prospects for small and medium enterprises. Problems and Perspectives in Management, 17(4), 131-140. https://doi. org/10.21511/ppm.17(4).2019.11

2. Alzahrani, J. (2019). The impact of e-commerce adoption on business strategy in Saudi Arabian small and medium enterprises (SMEs). Review of Economics and Political Science, 4(1), 73-88. https://doi. org/10.1108/REPS-10-2018-013

3. Anderson, R. M., Heesterbeek, H., Klinkenberg, D., \& Hollingsworth, 
T. D. (2020). How will countrybased mitigation measures influence the course of the COVID-19 epidemic? The Lancet, 395(10228), 931-934. https://doi.org/10.1016/ S0140-6736(20)30567-5

4. Awiagah, R., Kang, J., \& Lim, J. I. (2016). Factors affecting e-commerce adoption among SMEs in Ghana. Information Development, 32(4), 815-836. https://doi. org/10.1177/0266666915571427

5. Bartik, A. W., Bertrand, M., Cullen, Z. B., Glaeser, E. L., Luca, M., \& Stanton, C. T. (2020). How Are Small Businesses Adjusting to COVID-19? Early Evidence from a Survey (NBER Working Paper No. 26989). Retrieved from https://www. nber.org/system/files/working_papers/w26989/w26989.pdf

6. Bircan, C., de Haas, R., Schweiger, H., \& Stepanov, A. (2020, June 3). Coronavirus credit support: Don't let liquidity lifelines become a golden noose. VOX CEPR. Retrieved from https://voxeu.org/article/coronavirus-credit-support-don-t-let-liquidity-lifelines-become-golden-noose

7. Botha, J.A.R., Bothma, C.H., Geldenhuys, P., Singh, A.M., Van Der Merwe, D., Booysen, H. \& Fourie, I. (2004). Managing E-commerce. Paarl: Juta \& Co.

8. BPS. (2019). Analisis Hasil SE2016 Lanjutan Potensi Peningkatan Kinerja Usaha Mikro Kecil. Badan Pusat Statistik. (In Indonesian). Retrieved from https://www.bps. go.id/publication/2019/03/05/669 12048b475b142057f40be/analisishasil-se2016-lanjutan-potensi-peningkatan-kinerja-usaha-mikro-kecil. html

9. Breckova, P., \& Karas, M. (2020). Online technology and promotion tools in SMEs. Innovative Marketing, 16(3), 85-97. https://doi. org/10.21511/im.16(3).2020.08

10. Brewera, P., \& Sebby, A. G. (2021). The effect of online restaurant menus on consumers' purchase intentions during the COVID-19 pandemic. International Journal of Hospitality Management, 94, 102777. https://doi.org/10.1016/j. ijhm.2020.102777

11. Briozzo, A., \& Cardone-Riportella, C. (2012). Evaluating the impact of public programs of financial aid to SMEs during times of crisis: The Spanish experience (Working Papers 12.04). Department of Financial Economics and Accounting, Universidad Pablo de Olavide. Retrieved from https://ideas.repec. org/p/pab/fiecac/12.04.html

12. Busnetti, I., \& Tambunan, T. (2020). Gap between Regions in the Use of E-Commerce by MSEs: Macrolevel Research Using Provincial Data from Indonesia. Journal of Telecommunications and the Digital Economy, 8(4), 37-63. Retrieved from https://jtde.telsoc.org/index. php/jtde/article/view/303

13. Cacioppo, J. T., \& Hawkley, L. C. (2009). Perceived social isolation and cognition. Trends in Cognitive Sciences, 13(10), 447-454. https://doi. org/10.1016/j.tics.2009.06.005

14. Campbell, A. M. (2020). An increasing risk of family violence during the Covid-19 pandemic: Strengthening community collaborations to save lives. Forensic Science International: Reports, 2, 100089. https://doi.org/10.1016/j. fsir.2020.100089

15. Chatterjee, R., Shiwaku, K., Gupta, R.D., Nakano, G., \& Shaw, R. (2015). Bangkok to Sendai and beyond: Implications for disaster risk reduction in Asia. International Journal of Disaster Risk Science, 6(2), 177-188. https://doi.org/10.1007/ s13753-015-0055-4

16. Deloitte. (2021). Realising the potential of Indonesia's digital economy. Retrieved from https:// www2.deloitte.com/content/dam/ Deloitte/id/Documents/about-deloitte/id-about-dip-edition-2-chapter-4-en-feb2021.pdf

17. Gourinchas, P., Kalemli-Özcan, S., Penciakova, V., \& Sander, N. (2020). COVID-19 and business failures. OECD. Retrieved from https://www. oecd.org/global-forum-productivity/webinars/Gourinchas-KalemliOzcan-covid-19-and-businessfailures.pdf

18. Hamad, H., Elbeltagi, I., \& ElGohary, H. (2018). An empirical investigation of business-to business e-commerce adoption and its impact on SMEs competitive advantage: the case of Egyptian manufacturing SMEs. Strategic
Change, 27(3), 209-229. https://doi. org/10.1002/jsc.2196

19. Hermina, N., Syahvianto, T. M., \& Yansa, B. (2020). Second Order Model Structural Equation Modeling for Analyzing External Environmental and Capability on Company Performance of Small and Medium Enterprise (SME) in Indonesia. PalArch's Journal of Archaeology of Egypt/Egyptology, 17(5), 562-580. Retrieved from https://archives.palarch.nl/index. php/jae/article/view/2855

20. Ho, L. (2011). Meditation, learning organizational innovation and performance. Industrial Management \& Data Systems, 111(1), 113-131. https://doi. org/10.1108/02635571111099758

21. Igwe, P. A., Amaugo, A. N., Ogundana, O. M., Egere, O. M., \& Anigbo, J. M. (2018). Factors affecting the investment climate, SMEs productivity and entrepreneurship in Nigeria. European Journal of Sustainable Development, 7(1), 182-200. https://doi.org/10.14207/ ejsd.2018.v7n1p182

22. ILO. (2020). Supporting small and medium enterprises through the COVID-19 crisis. Retrieved from https://www.ilo.org/jakarta/info/ public/pr/WCMS_741502/lang--en/ index.htm

23. Juergensen, J., Guimón, J., \& Narula, R. (2020). European SMEs amidst the COVID-19 crisis: Assessing impact and policy responses. Journal of Industrial and Business Economics, 47, 499-510. https://doi. org/10.1007/s40812-020-00169-4

24. Kaya, H.P., \& Uzay, S. (2017). The risks that will threaten going concern and control recommendations: Case study on SMEs. The Journal of Accounting and Finance, 46-64. Retrieved from https://dergipark.org.tr/tr/download/article-file/435914

25. Keogh-Brown, M. R., Jensen, $H$. T., Edmunds, W. J., \& Smith, R. D. (2020). The impact of Covid-19, associated behaviours and policies on the UK economy: A computable general equilibrium model. SSM - Population Health, 12, 100651. https://doi.org/10.1016/j. ssmph.2020.100651 
26. Laudon, K. C., \& Traver, C. G. (2017). E-Commerce 2016: business, technology, society $\left(12^{\text {th }}\right.$ ed.). Pearson.

27. Lewnard, J. A., \& Lo, N. C. (2020) Scientific and ethical basis for social-distancing interventions against COVID-19. The Lancet Infectious Diseases, 20(6), 631-633. https://doi.org/10.1016/S14733099(20)30190-0

28. Li, P., \& Xie, W. (2012). A strategic framework for determining e-commerce adoption. Journal of Technology Management in China, 7(1), 22-35. https://doi. org/10.1108/17468771211207321

29. Liu, S., \& Parilla, J. (2020, May 29). Small businesses have received uneven relieffrom COVID-19 federal aid. Brookings. Retrieved from https://www.brookings.edu/blog/ the-avenue/2020/05/29/how-thepaycheck-protection-program-iscoming-to-ground-in-the-nationslarge-metro-areas/

30. Lu, Y., Wu, J., Peng, J., \& Lu, L. (2020). The perceived impact of the covid-19 epidemic: Evidence from a sample of 4807 SMEs in Sichuan Province, China. Environmental Hazards, 19(4), 323-340. https:// doi.org/10.1080/17477891.2020.17 63902

31. Lubna, A. H., \& Baharudin, A. S. (2017). Factors affecting small and medium enterprises (SMEs) continuance intention to adopt e-commerce in Jordan. International Journal of Advanced and Applied Sciences, 4(4), 110-117. https://doi. org/10.21833/ijaas.2017.04.016

32. Lutfi, M., Buntuang, P. C. D., Kornelius, Y., Erdiyansyah, \& Hasanuddin, B. (2020). The impact of social distancing policy on small and medium-sized enterprises (SMEs) in Indonesia. Problems and Perspectives in Management, 18(3), 492-503. https://doi.org/10.21511/ ppm.18(3).2020.40

33. Mbuyisa, B., \& Leonard, A. (2017). The role of ICT use in SMEs towards poverty reduction: A systematic literature review. Journal of International Development, 29(2), 159-197. https://doi.org/10.1002/ jid. 3258

34. Molla, A., \& Heeks, R. (2007). Exploring E-Commerce Benefits for Businesses in a Developing Country. The Information Society, 23(2), 95-108. https://doi. org/10.1080/01972240701224028

35. Nooteboom, B. (2006). Transaction Costs, Innovation and Learning (CentER Discussion Paper 2006-36). Tilburg: Organization. Retrieved from https://research.tilburguniversity.edu/en/publications/ transaction-costs-innovation-andlearning-2

36. Nowland, R., Necka, E. A., \& Cacioppo, J. T. (2018). Loneliness and social internet use: Pathways to reconnection in a digital world? Perspectives on Psychological Science, 13(1), 70-87. https://doi. org/10.1177/1745691617713052

37. Rahayu, R., \& Day, J. (2015). Determinant Factors of E-commerce Adoption by SMEs in Developing Country: Evidence from Indonesia. Procedia - Social and Behavioral Sciences, 195, 142-150. https://doi.org/10.1016/j. sbspro.2015.06.423

38. Rahayu, R., \& Day, J. (2017). E-commerce adoption by SMEs in developing countries: evidence from Indonesia. Eurasian Business Review, 7(1), 25-41. https://doi.org/10.1007/ s40821-016-0044-6

39. Revoltella, D., Maurin, L., \& Pal, R. (2020). EU firms in the postCOVID-19 environment: Investmentdebt trade-offs and the optimal sequencing of policy responses. VOX CEPR. Retrieved from https://voxeu. org/article/eu-firms-post-covid19-environment

40. Saidu, M., \& Aifuwa, H. O. (2020). Coronavirus Pandemic in Nigeria: How Can Small and Medium Enterprises (SMEs) Cope and Flatten the Curve. European Journal of Accounting, Finance and Investment, 6(5), 55-61.

41. Sharma, M.K., \& Bhagwat, R. (2006). Practice of information systems: Evidence from select Indian SMEs. Journal of Manufacturing Technology Management, 17(2), 199-223. https://doi. org/10.1108/17410380610642278

42. Ssenyonga, M., \& Shafiullah, M. (rev. ed.). (2021). Imperatives for post COVID-19 recovery of Indonesias education, labor, and SME sectors. Cogent Economics \& Finance, 9(1), 1911439. https://doi.org/10.1080/23 322039.2021.1911439

43. Syaifullah, J., Syaifudin, M., Sukendar, M. U., \& Junaedi, J. (2021). Social Media Marketing and Business Performance of MSMEs During the COVID-19 Pandemic. The Journal of Asian Finance, Economics and Business, 8(2), 523-531. https://doi.org/10.13106/ JAFEB.2021.VOL8.NO2.0523

44. Tairas, D. R. (2020). Covid-19 pandemic and MSMEs: Impact and mitigation. Jurnal Ekonomi Indonesia, 9(1), 67-80. https://doi org/10.52813/jei.v9i1.48

45. Tapscott, D. (2001, July 1). Rethinking strategy in a networked world (or why Michael Porter is wrong about the Internet). Strategy+Business. Retrieved from https://www.strategy-business.com/ article/19911

46. Thorgren, S., \& Williams, T. A. (2020). Staying alive during an unfolding crisis: How SMEs ward off impending disaster. Journal of Business Venturing Insights, 14, e00187. https://doi.org/10.1016/j. jbvi.2020.e00187

47. Turban, E. (2010). Electronic commerce 2010: a managerial perspective. Upper Saddle River: Pearson Education.

48. Yoshino, N., \& Taghizadeh-Hesary, F. (2018). The role of SMEs in Asia and their difficulties in accessing finance (ADBI Working Papers). Asian Development Bank Institute. Retrieved from https://www.adb. org/sites/default/files/publication/474576/adbi-wp911.pdf

49. Yudaruddin, R. (2014). Statistik Ekonomi: Aplikasi Dengan Program SPSS Versi 20. Interpena Yogyakarta. (In Indonesian).

50. Yudaruddin, R. (2020).

Determinants of micro-, small-and medium-sized enterprise loans by commercial banks in Indonesia. The Journal of Asian Finance, Economics and Business, 7(9), 19-30. https://doi. org/10.13106/JAFEB.2020.VOL7. NO9.019 